\title{
MODUL PEMBELAJARAN MATEMATIKA BERBASIS PISA UNTUK MELATIH SISWA BERPIKIR TINGKAT TINGGI
}

\author{
Nurdin Mohayat ${ }^{1} \&$ Netriwati $^{2}$ \\ 12 UIN Raden Intan Lampung, Bandar Lampung/Lampung, Indonesia \\ 1nurdinmoehayat@gmail.com, 2netriwati@gmail.com
}

\begin{abstract}
Abstrak
Penelitian ini bertujuan untuk mengembangkan modul pembelajaran matematika berbasis soal PISA untuk melatih kemampuan siswa dalam berpikir tingkat tinggi. Jenis penelitian ini adalah penelitian dan pengembangan. Penelitian ini menggunakan 7 tahap dari 10 tahap prosedur dari borg and gall yang sudah dimodifikasi oleh sugiyono. Teknik pengumpulan data yang digunakan adalah dokumen, wawancara dan angket penilaian. Hasil penelitian adalah modul pembelajaran matematika berbasis soal-soal PISA untuk melatih siswa dalam meningkatkan kemampuan berpikir tingkat tinggi siswa yang telah dinyatakan valid dan layak digunakan secara keseluruhan sebagai media pembelajaran oleh 3 Ahli materi yang memperoleh skor rata-rata $84,2 \%$ dan 3 Ahli media yang memperoleh skor rata-rata $87 \%$ dengan masing-masing skor maksimal kevalidan adalah $100 \%$. Sedangkan uji kemenarikan media pembelajaran dinyatakan "Sangat Menarik" oleh uji kelompok kecil yang memperoleh skor rata-rata $80,45 \%$ dan uji kelompok besar dengan skor ratarata 85,85\% dengan masing-masing skor maksimal kemenarikan adalah 100\%. Sehingga dapat disimpulkan pengembagan modul matematika yang dihasilkan dinyatakan layak dan dapat digunakan sebagai bahan ajar untuk melatih siswa dalam meningkatkan pemahaman tingkat tinggi.
\end{abstract}

Kata kunci: Berpikir tingkat tinggi; modul matematika; PISA;

\begin{abstract}
This study aims to develop a PISA-based learning module in mathematics to train students' high-order thinking skills. This research type is research and mining. This research uses 7 stages from 10 stages of procedure from Borg and Gall which have been modified by Sugiyono. Data collection techniques used are documents, interviews and assessment questionnaires. The result of the research is the learning module of mathematics based on PISA problems to train students in improving students' high thinking ability which has been declared valid and proper to be used as a whole as a medium of learning by 5 material experts who got the average score of $84.2 \%$ and 3 Experts media that scored an average of $87 \%$ with each of the maximum validity scores was $100 \%$. While the attractiveness test of instructional media stated "Very Interesting" by small group test which got average score $80,45 \%$ and big group test with score average $85,85 \%$ with each score maximal attractiveness is $100 \%$. So it can be concluded that the development of the resulting
\end{abstract}


Mohayat, N., \& Netriwati, N. (2018). MODUL PEMBELAJARAN MATEMATIKA BERBASIS PISA UNTUK MELATIH SISWA BERPIKIR TINGKAT TINGGI. Jurnal Tatsqif, 16(1), 93-107. Retrieved from http://journal.uinmataram.ac.id/index.php/tatsqif/article/view/135

mathematical module is declared feasible and can be used as a teaching material to train students in improving high comprehension. Keywords: High Order Thinking; Math Module; PISA;

\section{PENDAHULUAN}

Salah satu tujuan nasional bangsa Indonesia di dalam pembukaan UndangUndang Dasar Negara Republik Indonesia tahun 1945 adalah untuk mencerdaskan kehidupan bangsa. Pencapaian tujuan nasional untuk mencerdaskan kehidupan bangsa dilakukan melalui pendidikan. Pendidikan melibatkan kegiatan belajar dan proses pembelajaran. Menurut Mulya dalam (Kusuma, 2017) Sebagai salah satu faktor dalam proses pelaksanaan pembelajaran, guru selalu dituntut untuk meningkatkan kualitasnya dalam pembelajaran. Kualitas guru dapat ditinjau dari dua segi, yaitu segi proses dan dari segi hasil. Dari segi proses, guru dapat dikatakan berhasil apabila mampu melibatkan sebagian besar peserta didik secara aktif, baik fisik, mental, maupun sosial dalam pembelajaran. Sedangkan dari segi hasil, guru dikatakan berhasil apabila pembelajaran yang diberikannya mampu memberikan hasil yang yeng telah mencapai kriteria minimal nilai yang diharapkan dari proses pembelajaran yang telah dilakukan terutama dalam pembelajaran matematika karna pelajaran matematika adalah pelajaran yang kompleks dari semua tingkatan.

Menurut (Pangesti \& Retnowati, 2017) Mempelajari matematika itu harus runtun dan berkesinambungan karena konsepnya saling berkaitan matematika satu dengan matematika yang lain, maka dalam hal ini diperlukan ketrampilan siswa dalam berfikir tingkat tinggi guna menyinambungkan materi yang telah diterima dengan materi yang lain. Sejala dengan berfikir tingkat tinggi, saat ini terdapat program internasional yang fokus menangani hal tersebut, terutama di bidang matematika dan sains. Program tersebut adalah PISA (Program for International Student Assessment). PISA menekankan pada kreatifitas, kompetensi peserta didik, serta diharapkan 
Mohayat, N., \& Netriwati, N. (2018). MODUL PEMBELAJARAN MATEMATIKA BERBASIS PISA UNTUK MELATIH SISWA BERPIKIR TINGKAT TINGGI. Jurnal Tatsqif, 16(1), 93-107. Retrieved from http://journal.uinmataram.ac.id/index.php/tatsqif/article/view/135

dapat menerapkan ilmu pengetahuan yang didapat dalam kehidupan seharihari, dan dapat memecahkan berbagai masalah yang dihadapi. PISA merupakan suatu studi bertaraf internasional yang diselenggarakan oleh Organization for Economic Cooperation and Development (OECD) yang bertujuan untuk melihat kemampuan berpikir peserta didik sejak usia 15 tahun yang diikuti oleh beberapa negara-negara maju dan berkembang, termasuk Indonesia. Program ini dikembangkan untuk mengukur peserta didik pada usia tersebut telah menguasai apa yang seharusnya mampu dicapai, serta peserta didik mampu mengaplikasikan pengetahuaannya dalam kehidupan sehari-hari(Anisah, Zulkardi, \& Darmawijoyo, 2013). Namu pada kenyataannya hasil study PISA masih belum emmeberikan kabar yang menggembirakan.

Hasil studi PISA tahun 2015 menunjukkan Indonesia masih dalam peringkat yang rendah, Indonesia masuk dalam peringkat 69 dari 76 negara di dunia yang terdaftar dalam PISA. Survei ini dilaksanakan oleh OECD (Organisation for Economic Cooperation and Development) dalam (Johar, 2012a) yang menggunakan analisis standar global yang lebih luas menggunakan tes PISA. Dalam kompetensi matematika pada tahun 2015 mengalami peningkatan yang signifikan, yaitu dari poin 375 pada tahun 2012 menjadi 386 poin. Dengan rendahnya studi PISA ini, akan berdampak pula akan rendahnya kemampaun berfikir tingkat tinggi siswa. Hal ini didukung oleh (Kurniati, Harimukti, \& Jamil, 2016) yang mengungkapkan bahwa Soalsoal PISA bukan hanya menuntut kemampuan dalam penerapan konsep saja, tetapi juga menuntut siswa menalar dalam berfikir tingkat tinggi.

Melihat masalah diatas akan petingnya kemampuan berpikir tingkat tinggi siswa, maka penulis melihat perlu adanya suatu inovasi untuk pembelajaran matematika dalam rangka kemampuan berpikir tingkat tinggi siswa. Dalam mengatasi permasalah yang telah dipaparkan sebelumnya, penulis berminat mengembangkan bahan ajar berupa modul pembelajaran matematika berbasis soal-soal PISA dengan harapan membantu siswa dalam melatih untuk 
Mohayat, N., \& Netriwati, N. (2018). MODUL PEMBELAJARAN MATEMATIKA BERBASIS PISA UNTUK MELATIH SISWA BERPIKIR TINGKAT TINGGI. Jurnal Tatsqif, 16(1), 93-107. Retrieved from http://journal.uinmataram.ac.id/index.php/tatsqif/article/view/135

meningkatkan kemampuan berpikir tingkat tinggi siswa. Penelitian dengan

mengembangkan bahan ajar berupa modul pembelajaran matematika pernah dilakukan sebelumnya yang telah mampu membantu siswa dalam meningkatkan kemampuan pemecahan masalah matematis, pemahaman konsep serta hasil belajar siswa (Aji, Hudha, \& Rismawati, 2017; Ansori, Sunarno, \& Suparmi, 2017; Citroresmi, Sugiatno, \& Suratman, 2016). Namun penulis melakukan keterbaharuan dalam penelitian ini yaitu dengan mengembangkan modul sebagai bahan ajar matematika berbasis soal-soal PISA untuk melatih siswa dalam meningkatkan kemampuan berpikir tingkat tinggi.

\section{LANDASAN TEORI}

PISA (Program for International Student Assesment) merupakan suatu studi bertaraf internasional yang diselenggarakan oleh OECD (Organization for Economic Cooperation and Development) yang mengkaji kemampuan literasi siswa pada rentang usia 15-16 tahun yang diikuti oleh beberapa negara peserta, termasuk Indonesia(Ray \& Margaret, 2003). Fokus dari PISA adalah literasi yang menekankan pada keterampilan dan kompetensi siswa yang diperoleh dari sekolah dan dapat digunakan dalam kehidupan sehari-hari dan dalam berbagai situasi(Johar, 2012b).

PISA merupakan studi Internasional tentang prestasi membaca, matematika dan sains siswa sekolah berusia 15 tahun. Indonesia sendiri telah ikut tes ini sejak tahun 2000. Dalam hasil studi PISA tahun 2015, peningkatan terbesar terlihat pada kompetensi sains, dari 382 poin pada tahun 2012 menjadi 403 poin di tahun 2015. Dalam kompetensi matematika meningkat dari 375 poin di tahun 2012 menjadi 386 poin di tahun 2015. Kompetensi membaca mengalami peningkatan dari 396 di tahun 2012 menjadi 397 poin di tahun 2015("The Assessment of Learning Contexts in PISA | SpringerLink," t.t.)

Literasi matematika merupakan salah satu domain yang diukur dalam studi PISA. Literasi matematika didefinisikan sebagai kemampuan seseorang 
merumuskan, menggunakan, dan menafsirkan matematika dalam konteks yang bervariasi, yang melibatkan penggunaan penalaran matematis, konsep, fakta, prosedur, dan alat-alat yang menggambarkan, yang membantu seseorang untuk mengenal kegunaan matematika dalam kehidupan seharihari(Abidin, Mulyati, \& Yunansah, 2015).

Dalam PISA terdapat tiga komponen utama, yaitu konten (content), konteks (context), matematika, dan kompetensi (competency) atau kemampuan matematis, yang terlihat seperti gambar berikut:

\section{a. Konten (Content)}

Masalah pada PISA meliputi konten (content) matematika yang berkaitan dengan fenomena. Dalam PISA fenomena ini dikenal dengan over-arching ideas. Karena domain matematika sangat banyak dan bervariasi, tidak mungkin untuk mengidentifikasi secara lengkap..

b. Konteks (Context)

Situasi yang tergambar dalam suatu permasalahan yang diujikan yang dapat terdiri atas konteks pribadi (personal), konteks pekerjaan (occupational), konteks sosial (social) dan konteks ilmu pengetahuan (scientific). Oleh karena itu, soal-soal yang diberikan dalam PISA disajikan sebagian besar dalam situasi dunia nyata sehingga dapat dirasakan manfaat matematika itu untuk memecahkan permasalahan kehidupan keseharian.

c. Kompetensi (Competencies)

Untuk menyelesaikan suatu permasalahan dalam situasi tertentu dengan menggunakan matematika, diperlukan juga kemampuan proses dapat didefinisikan sebagai kemampuan seseorang dalam merumuskan (formulate), menggunakan (employ) dan menafsirkan (interpret) matematika untuk memecahkan masalah yang melibatkan kemampuan dalam komunikasi, matematisasi, representasi, penalaran dan argumentasi, menentukan strategi untuk memecahkan masalah, penggunaan bahasa simbol, bahasa formal, dan bahasa teknis sebagai alat matematika. 
Mohayat, N., \& Netriwati, N. (2018). MODUL PEMBELAJARAN MATEMATIKA BERBASIS PISA UNTUK MELATIH SISWA BERPIKIR TINGKAT TINGGI. Jurnal Tatsqif, 16(1), 93-107. Retrieved from http://journal.uinmataram.ac.id/index.php/tatsqif/article/view/135

\section{METODE}

Jenis penelitian ini adalah penelitian dan pengembangan (R\&D). Prosedur pengembangan yang digunakan adalah metode Borg and Gall. (Sugiyono, 2010) menjelaskan ada 10 tahapan langkah dari metode Borg and Gall. Dikarenakan keterbatasan peneliti dalam penelitian ini baik dari segi waktu, kemampuan maupun dari segi biaya maka penelitian ini dibatasi hanya sampai 7 tahap yaitu :

1. Potensi dan masalah

2. Mengumpulkan imformasi

3. Desain produk

4. Validasi desain

5. Perbaikan produk

6. Uji coba lapangan

7. Revisi produk

Teknik Pengumpulan data yang dilakukan yaitu dengan dokumen, wawancara dan penyebaran angket skala likert dengan 5 jawaban. Penskoran yang digunakan dalam penilaian validasi ahli dapat dilihat pada Tabel 1.

Tabel 1.

Skor presentase penilaian validasi para ahli

\begin{tabular}{cl|}
\hline Skor presentasi & \multicolumn{1}{c|}{ interpretasi } \\
\hline $0 \% \leq \mathrm{x} \leq 20 \%$ & Sangat tidak layak \\
$20 \%<\mathrm{x} \leq 40 \%$ & Kurang layak \\
$40 \%<\mathrm{x} \leq 60 \%$ & Cukup layak \\
$60 \%<\mathrm{x} \leq 80 \%$ & Layak \\
\hline $80 \%<\mathrm{x} \leq 100 \%$ & Sangat layak \\
\hline
\end{tabular}

Sedangkan penskoran uji kemenarikan produk dapat dilihat pada Tabel 2.

Tabel 2.

Skor presentase uji kemenarikan peserta didik

\begin{tabular}{cl|}
\hline Skor presentasi & \multicolumn{1}{c|}{ Interpretasi } \\
\hline $0 \% \leq \mathrm{x} \leq 20 \%$ & Sangat tidak menarik \\
$20 \%<\mathrm{x} \leq 40 \%$ & Kurang menarik \\
$40 \%<\mathrm{x} \leq 60 \%$ & Cukup menarik \\
$60 \%<\mathrm{x} \leq 80 \%$ & Menarik \\
$80 \%<\mathrm{x} \leq 100 \%$ & Sangat menarik \\
\hline
\end{tabular}


Mohayat, N., \& Netriwati, N. (2018). MODUL PEMBELAJARAN MATEMATIKA BERBASIS PISA UNTUK MELATIH SISWA BERPIKIR TINGKAT TINGGI. Jurnal Tatsqif, 16(1), 93-107. Retrieved from http://journal.uinmataram.ac.id/index.php/tatsqif/article/view/135

Skor penilaian total dalam analisa data dapat dicari dengan rumus berikut:

$\mathrm{P}=\frac{\mathrm{F}}{\mathrm{N}} \times 100 \%$

Keterangan :

$\mathrm{P}=$ Angka presentase data angket

$\mathrm{F}=$ Jumlah skor yang diperoleh

$\mathrm{N}=$ Jumlah skor maksimum

\section{HASIL DAN PEMBAHASAN}

Penelitian ini menghasilkan sebuah modul berbasis soal-soal PISA untuk melatih kemampuan berpikir tingkat tinggi siswa. Tahapan yang digunakan dalam penelitian dan pengembangan ini menggunakan prosedur Borg and Gall 7 tahapan dari 10 tahapan. Tahapan tahapan itu diantaranya :

a. Potensi dan masalah

Dalam tahapan ini masalah ditemukan berdasarkan hasil wawancara kepada guru matematika di SMP Al Kautsar Bandar Lampung bahwa Pengetahuan pendidik tentang soal PISA masih kurang, Literasi matematika belum diprogramkan pada Sekolah Menengah Pertama., Peserta didik mengalami kesulitan dalam belajar menggunakan buku, karena tebalnya buku dan materi selain itu minimnya bahan ajar berupa modul yang berbasis soalsoal PISA sehingga mengakibatkan Kemampuan berpikir tingkat tinggi yang masih rendah. Merujuk masalah tersebut, penulis memanfaatkan sebuah potensi untuk mengembangkan bahan ajar berupa modul pembelajaran berbasis soal-soal PISA

b. Mengumpulkan Imformasi

Pada tahapan ini penneliti melakukan beberapa studi pustaka dari beberapa literatur buku, soal-soal berbasis PISA dan beberapa jurnal yang mendukung, dan diperoleh produk yang akan dikembangkan berupa pengembangan bahan ajar modul berbasis soal-soal PISA

c. Desain Produk 
Setelah analisis kebutuhan, maka selanjutnya tahap pembuatan media. Dalam tahap ini, peneliti tidak serta merubah isi materi yang ada. Namun menggabungkan materi dari beberapa sumber yang sesuai dengan soal-soal PISA, kemudian di desain lebih menarik dengan memperhatikan standar kelayakan penyajian, dan standar kelayakan kebahasaan.

d. Validasi Desain

Setelah desain produk selesai, kemudian dilakukan penilaian oleh para ahli materi dan Ahli media. Dari masing masing penilaian yang diberikan oleh validator ahli, media pembelajaran yang dikembangkan dinyatakan valid dan layak digunakan sebagai media pembelajaran setelah dilakukan revisi. Untuk hasil validasi dapat dilihat pada tabel 3.

Tabel 3.

Hasil validasi ahli materi sebelum dan sesudah revisi

\begin{tabular}{llcccc}
\hline No & \multicolumn{1}{c}{ Aspek } & $\begin{array}{c}\text { Skor peroleh } \\
\text { sebelum } \\
\text { revisi (\%) }\end{array}$ & Kriteria & $\begin{array}{c}\text { Skor perolehan } \\
\text { sesudah revisi } \\
\text { (\%) }\end{array}$ & Criteria \\
\hline 1 & Kualitas isi & 73 & Layak & 82 & Sangat Layak \\
2 & Kebahasaan & 75 & Layak & 84 & Sangat Layak \\
3 & Keterlakasanaan & 71 & Layak & 80 & Layak \\
4 & Tampilan visual & 78 & Layak & 88 & Sangat Layak \\
5 & Kemanfaatan & 77 & Layak & 87 & Sangat Layak \\
\hline
\end{tabular}

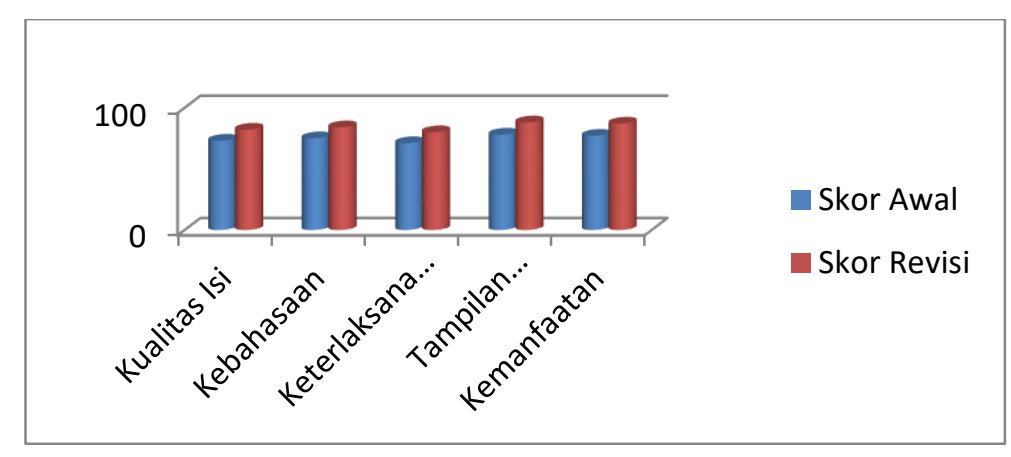

Diagram 1.

Hasil presentase validasi ahli materi sesudah dan sebelum revisi.

Berdasarkan tabel 3. Dapat dilihat bahwa dari berbagai aspek mengalami peningkatan setelah dilakukan revisi media dari saran dan masukan para ahli. Peningkatan itu diantaranya Aspek kualitas dari perolehan skor 73\% meningkat menjadi skor $82 \%$ dengan kriteria sangat layak, aspek kebahasaan 
dari perolehan skor 75\% meningkat menjadi $84 \%$ dengan kriteria sangat layak, aspek keterlaksanaan dari perolehan skor 71\% meningkat menjadi skor 80\% dengan kriteria layak, aspek tampilan visual dari perolehan skor 78\%

meningkat menjadi skor $88 \%$ dengan kriteria sangat layak dan aspek kemanfaatan dari perolehan skor 77\% meningkat menjadi skor 87\% dengan kriteria sangat layak. Berdasarkan hal ini maka media layak untuk dilakukan uji coba berdasarkan penilaian para ahli materi.

Selain dari ahli materi, dilakukan juga validasi bahan ajar yang telah dikembangkan kepada ahli media guna melihat tampilan design bahan ajar . hasil validasi kepada para ahli media dapat dilihat pada tabel 4.

Tabel 4.

Hasil validasi oleh ahli media sebelum dan sesudah revisi

\begin{tabular}{|c|c|c|c|c|c|}
\hline No & Aspek & $\begin{array}{c}\text { Skor } \\
\text { perolehan } \\
\text { sebelum } \\
\text { revisi }\end{array}$ & Kriteria & $\begin{array}{c}\text { Skor } \\
\text { perolehan } \\
\text { sesudah revisi }\end{array}$ & kriteria \\
\hline 1 & Tampilan modul & 77 & Layak & 89 & Sangat Layak \\
\hline 2 & $\begin{array}{l}\text { Kemenarikan } \\
\text { modul }\end{array}$ & 73 & Layak & 88 & Sangat Layak \\
\hline 3 & $\begin{array}{l}\text { Kemudahan } \\
\text { penggunaan }\end{array}$ & 72 & Layak & 84 & Sangat Layak \\
\hline
\end{tabular}

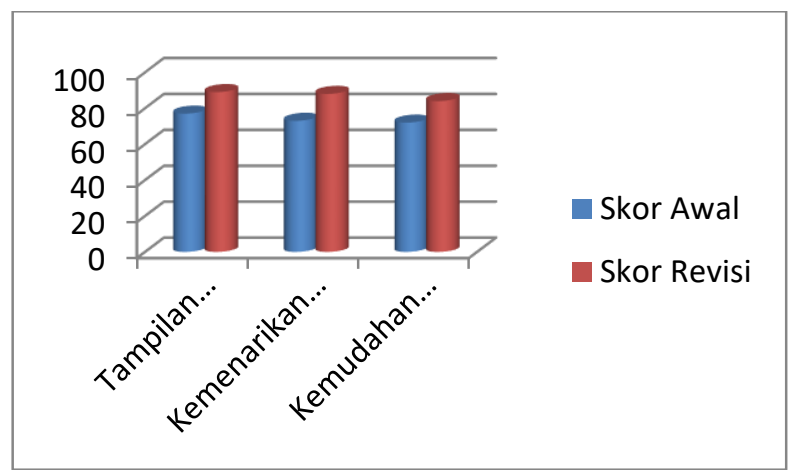

Diagram 2.

Hasil presentase validasi ahli media sesudah dan sebelum revisi

Berdasarkan tabel 4. Dapat dilihat bahwa juga terjadi peningkatan pada validasi tahap 2 setelah dilakukan perbaikan berdasarkan saran dan masukan para ahli saat dilakukan vaildasi tahap 1. Peningkatan itu diantaranya pada aspek tampilan modul dadri perolehan skor 77 meningkat menjadi skor 89, 
aspek kemenarikan modul dari perolehan skor 73\% meningkat menjadi 88\% dan aspek kemudahan penggunaan dari perolehan skor 72\% meningkat menjadi 84\% dengan masing-masing kriteria sangat layak. Berdasarkan hal ini maka bahan ajar dari segi tampilan media sudah sangat layak untuk dilakukan uji coba kepada peserta didik.

e. Perbaikan desain

Kelayakan dan kevalidan produk tidak terlepas dari masukan dan saran oleh para ahli. Perbaikan-perbaikan yang dilakukan terhadap produk yang dikembangkan berpedoman dari masukan-masukan dan saran yang diperoleh dari para ahli validasi. Masukan dan saran para ahli yang pertama bahwa pada bahan ajar sebaiknya menambahkan petunjuk penggunaan modul agar supaya mempermudah mempelajari modul yang dikembangkan. Setelah dilakukan revisi peneliti menambahkan form petunjuk penggunaan modul yang dapat dilihat pada gambar 1.

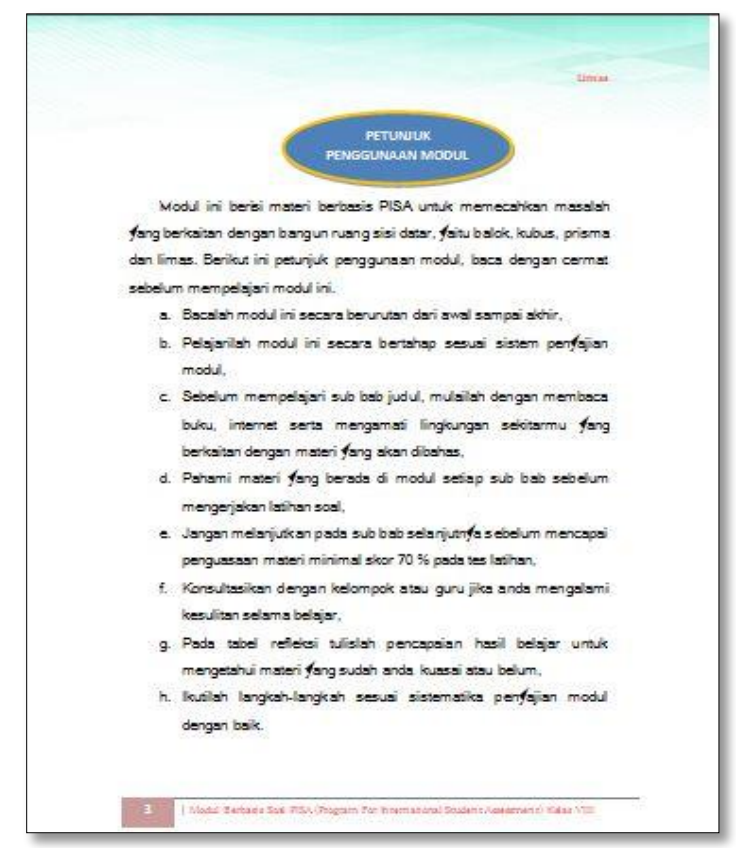

Gambar 1. Form petunjuk penggunaan modul

Selanjutnya perbaikan dilakukan perbaikan pada Soal yang dikembangkan ahli materi memberi masukan bahwa sebaiknya lebih diperbanyak dan disesuikan SK dan KD pembelajaran. Selain itu modul yang 
Mohayat, N., \& Netriwati, N. (2018). MODUL PEMBELAJARAN MATEMATIKA BERBASIS PISA UNTUK MELATIH SISWA BERPIKIR TINGKAT TINGGI. Jurnal Tatsqif, 16(1), 93-107. Retrieved from http://journal.uinmataram.ac.id/index.php/tatsqif/article/view/135

dikembangkan dapat melatih kemampuan berpikir tingkat tinggi peserta didik.

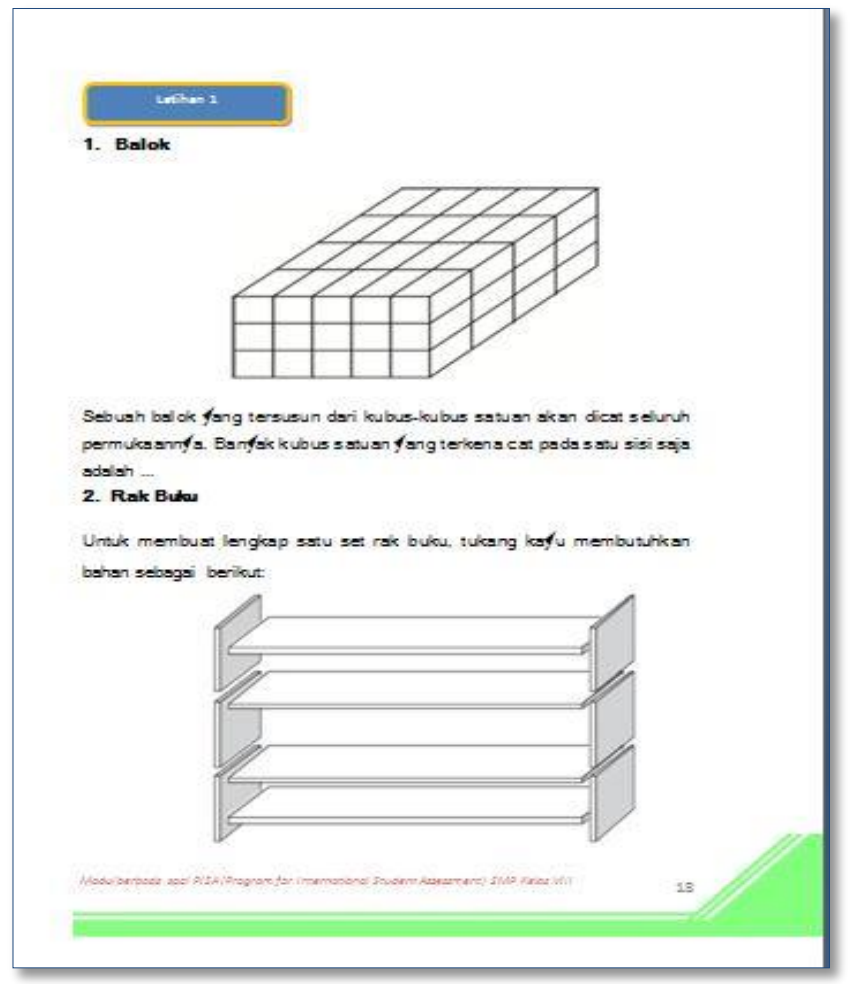

Gambar 2.

Form sebelum direvisi soal-soal dan sistematika penulisan modul 


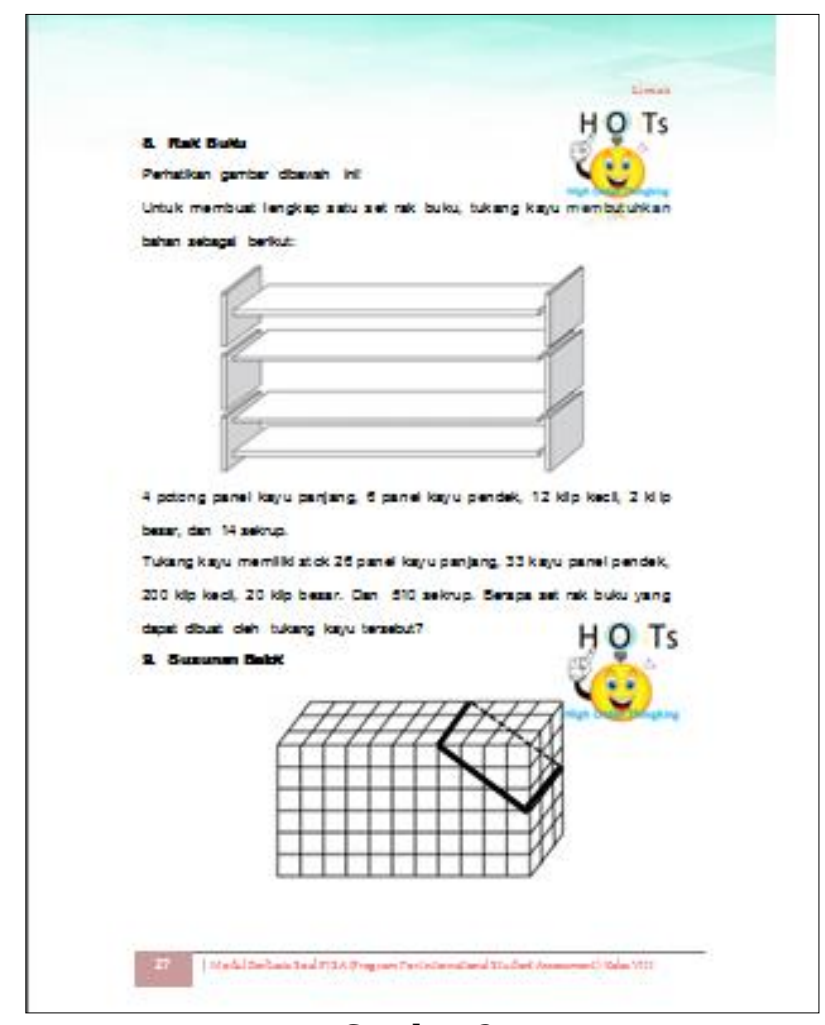

Gambar 3.

f. Uji coba lapangan

Form setelah direvisi soal-soal berbasis PISA

Uji Coba Produk dilakukan dalam 2 tahapan yaitu uji coba kelompok kecil yang terdiri dari 20 responden kelas VIII dan uji coba lapangan yang terdiri dari 60 responden. Pada tahapan uji coba kelompok kecil hasil pengujian yang diperoleh seperti pada Tabel 7 berikut:

Tabel 5.

Hasil uji coba modul matematika berbasis soal-soal PISA

\begin{tabular}{lccl|}
\hline Kelompok uji coba & Jumlah responden & Skor perolehan (\%) & Kriteria \\
\hline Kelompok kecil & 20 & 84,2 & Sangat menarik \\
Kelompok besar & 60 & 87 & Sangat menarik \\
\hline
\end{tabular}

Keterangan ; SM(Sangat Menarik) ; M(Menarik) ; CM(Cukukp Menarik) ;TM(Tidak Menarik). Dari pengujian data yang ditampilkan dalam tabel 5, tingkat kemenarikan produk pada uji coba kelompok kecil memperoleh skor rata-rata 84,2\% dengan kriteria "Sangat Menarik" dan uji coba kelompok besar mencapai skor rata-rata 87\% dengan kriteria "Sangat Menarik". Dalam hal ini peneliti menyimpulkan bahwa ada kemenarikan 
Mohayat, N., \& Netriwati, N. (2018). MODUL PEMBELAJARAN MATEMATIKA BERBASIS PISA UNTUK MELATIH SISWA BERPIKIR TINGKAT TINGGI. Jurnal Tatsqif, 16(1), 93-107. Retrieved from http://journal.uinmataram.ac.id/index.php/tatsqif/article/view/135

tersendiri pembelajaran dengan bantuan media pembelajaran didalam kelas.Revisi produk

Pada tahap ini revisi produk dilakukan apa bila terdapat kendala yang ditemukan pada saat produk diuji cobakan dan kemenarikan produk menyatakan produk dengan kriteria tidak menarik. Pada uji coba yang dilakukan peneliti diperoleh hasil uji coba dengan kriteria "sangat menarik" dan tidak terdapat kendala penggunaan yang ditemui sehingga produk tidak perlu dilakukan revisi kembali. Hasil penelitian ini sama dengan hasil penelitian sebelumnya bahwa modul matematika mampu mengatasi permasalahan-permasalahan yang ada dalam matematika antara lain kemmapuan pemahaman konsep pemecahan masalah matematis serta kemmpuan berfikir tingkat tinggi siswa (Anisah et al., 2013; Citroresmi et al., 2016, 2016; Pangesti \& Retnowati, 2017; Rosnanda, Sarwanto, \& Aminah, 2018).

\section{KESIMPULAN}

Berdasarkan data yang telah dibahas pada pokok bahasan sebelumnya maka dapa simpulkan bahwa penelitian dan pengembangan ini menghasilkan sebuah bahan ajar modul matematika berbasis soal-soal PISA untuk melatih siswa dalam meningkatkan kemapuan pemahaman tingkat tinggi siswa. Ditinjau dari kelayakan meodul berdasarkan hasil dari validasi oleh 3 Ahli materi yang memperoleh skor rata-rata 84,2\% dan 3 Ahli media yang memperoleh skor rata-rata 87\% dengan masing-masing skor maksimal kevalidan adalah 100\%. Sedangkan uji kemenarikan media pembelajaran dinyatakan "Sangat Menarik" oleh uji kelompok kecil yang memperoleh skor rata-rata 80,45\% dan uji kelompok besar dengan skor ratarata 85,85\% dengan masing-masing skor maksimal kemenarikan adalah 100\%. Sehingga dapat disimpulkan pengembagan modul matematika yang dihasilkan dinyatakan layak dan dapat digunakan sebagai bahan ajar untuk melatih siswa dalam meningkatkan pemahaman tngkat tinggi.

Berdasarkan kesimpulan yang telah dijelaskan diatas bahwa penulis menyarankan agar guru menggunakan bahan ajar modul berbasis soal-soal PISA 
Mohayat, N., \& Netriwati, N. (2018). MODUL PEMBELAJARAN MATEMATIKA BERBASIS PISA UNTUK MELATIH SISWA BERPIKIR TINGKAT TINGGI. Jurnal Tatsqif, 16(1), 93-107. Retrieved from http://journal.uinmataram.ac.id/index.php/tatsqif/article/view/135

dengan tujuan untuk melatih siswa dalam menmingkatkan kemampuan pemahaman tingkat tinggi siswa.

\section{DAFTAR PUSTAKA}

Aji, S., Hudha, M. N., \& Rismawati, A. (2017). Pengembangan Modul Pembelajaran Fisika Berbasis Problem Based Learning untuk Meningkatkan Kemampuan Pemecahan Masalah Fisika. SEJ (Science Education Journal), 1(1), 36-51.

Anisah, A., Zulkardi, Z., \& Darmawijoyo, D. (2013). Pengembangan soal matematika model PISA pada konten quantity untuk mengukur kemampuan penalaran matematis siswa sekolah menengah pertama. Jurnal Pendidikan Matematika, 5(1), 189-197.

Ansori, M. I. L., Sunarno, W., \& Suparmi, S. (2017). Pengembangan Modul Fisika Berbasis Inkuiri Terbimbing Pada Pokok Bahasan Listrik Dinamis Untuk Meningkatkan Keterampilan Berpikir Kritis Siswa Kelas X SMA/MA. INKUIRI Jurnal Pendidikan IPA, 6(2), 35-46.

Citroresmi, N., Sugiatno, \& Suratman, D. (2016). Pengembangan Modul Matematika Berbasis Masalah Untuk Meningkatkan Kemampuan Penyelesaian Masalah Dan Berpikir Kreatif Matematis Siswa. Jurnal Pendidikan Dan Pembelajaran, 5(4). Retrieved from

Johar, R. (2012). Domain Soal PISA untuk Literasi Matematika. Jurnal Peluang, $1(1), 30$.

Kurniati, D., Harimukti, R., \& Jamil, N. A. (2016). Kemampuan berpikir tingkat tinggi siswa SMP di kabupaten jember dalam menyelesaikan soal berstandar PISA. Jurnal Penelitian Dan Evaluasi Pendidikan, 20(2), 142155.

Kusuma, A. P. (2017). Implementasi Model Pembelajaran Student Teams Achievement Division dan Team Assisted Individualization ditinjau dari Kemampuan Spasial Siswa. Al-Jabar: Jurnal Pendidikan Matematika, 8(2), 135-144.

Pangesti, F. T. P., \& Retnowati, E. (2017). Pengembangan bahan ajar geometri SMP berbasis cognitive load theory berorientasi pada prestasi belajar siswa. Pythagoras: Jurnal Pendidikan Matematika, 12(1), 33.

Rosnanda, D., Sarwanto, S., \& Aminah, N. S. (2018). Pengembangan Modul Pembelajaran Berbasis Masalah Pada Materi Litosfer Untuk Meningkatkan 
Mohayat, N., \& Netriwati, N. (2018). MODUL PEMBELAJARAN MATEMATIKA BERBASIS PISA UNTUK MELATIH SISWA BERPIKIR TINGKAT TINGGI. Jurnal Tatsqif, 16(1), 93-107. Retrieved from http://journal.uinmataram.ac.id/index.php/tatsqif/article/view/135

Keterampilan Berpikir Kritis Siswa SMP. INKUIRI: Jurnal Pendidikan IPA, 6(3), 141-152. 